DOI 10.22460/infinity.v5i2.214

\title{
PROSPECTIVE TEACHERS' ABILITY IN MATHEMATICAL PROBLEM-SOLVING THROUGH REFLECTIVE LEARNING
}

\author{
Yunika Lestaria Ningsih ${ }^{1}$, Rohana ${ }^{2}$ \\ ${ }^{1,2}$ Department of Mathematics Education, PGRI Palembang University, South Sumatera, Indonesia \\ ${ }^{1}$ yunika@ univpgri-palembang.ac.id, ${ }^{2}$ rohana_pgri@yahoo.com
}

Received: May 30, 2016; Accepted: August 22, 2016

\begin{abstract}
The research aims to determine the mathematical problem-solving ability of prospective teachers' through reflective learning. Reflective learning is a learning process that provides students the opportunity to examine and investigate the problems that is triggered by experience, analyzing of individual the experiences, and facilitate the learning of the experiences. These lessons are identified to improve mathematical ability students. By using a descriptive qualitative research. The subject of this study were students of Mathematics Education Program in one of private universities in Palembang, consisting of 34 students. This study was conducted in odd semester academic year of 2015/2016. The instruments in this study were mathematical problem-solving ability test, observation sheet, and interview guide. The data were analyzed descriptively. Based on analysis of the data are found that the average mathematical problem-solving ability of students' through reflective learning in good categories.
\end{abstract}

Keywords: reflective learning, mathematical problem-solving ability

\begin{abstract}
Abstrak
Tujuan penelitian ini adalah untuk mengetahui kemampuan pemecahan masalah matematis mahasiswa calon guru melalui penerapan pembelajaran reflektif. Pembelajaran reflektif adalah suatu proses pembelajaran yang memberikan kesempatan kepada pebelajar untuk menguji dan menyelidiki persoalan yang menarik perhatian yang dipicu oleh pengalaman, melakukan analisis atas pengalaman individual yang dialami dan memfasilitasi pembelajaran dari pengalaman tersebut. Pembelajaran reflektif ini diidentifikasi dapat meningkatkan kemampuan matematis pebelajar. Penelitian ini menggunakan metode penelitian deskriptif kualitatif. Subjek penelitian ini adalah mahasiswa Program Studi Pendidikan Matematika FKIP Universitas PGRI Palembang semester genap tahun akademik 2015/2016 yang berjumlah 34 orang. Data penelitian dikumpulkan melalui tes dan wawancara. Data dianalisis secara deskriptif. Berdasarkan hasil analisis data diketahui bahwa rata-rata kemampuan pemecahan masalah matematis mahasiswa setelah diterapkan pembelajaran reflektif termasuk dalam kategori baik.
\end{abstract}

Kata Kunci: pembelajaran reflektif, kemampuan pemecahan masalah matematis

How to Cite: Ningsih, Y.L. \& Rohana (2016). Prospective Teachers' Ability in Mathematical Problem-Solving Through Reflective Learning. Infinity, 5 (2), 75-82. 


\section{INTRODUCTION}

According to the Regulation of the Minister of National Education in Indonesia Number 20/2006, the purposes of mathematics learning are students able to: (1) have knowledge of mathematics (the concept, the relationship between concepts and algorithms), (2) use of reasoning, (3) solve the problems, (4) communicate ideas through symbols, tables, diagrams, or other media to clarify the situation or problem, and (5) have an attitude that appreciate the usefulness of mathematics. Moreover, the purpose of learning mathematics is also formulated by the National Council of Teachers of Mathematics (2000), namely that the students have the competence: (1) to solve the problem; (2) reasoning; (3) communication; (4) relate the idea; and (5) positive attitudes towards mathematics.

Based on explanation above is known that the problem-solving ability is very important in learning mathematics. Arthur (2008) stated that problem-solving is a part of think. As part of the thinking, problem-solving exercises can improve high-level thinking ability that requires the modulation and control more over routine or basic skills. This opinion suggests that in problem-solving, the students not only require routine or basic skills, but also have a variety of other skills to manage all the thinking process in order to solve their problems. It means the students have control and sort ability all their knowledge, finally they can find the best way to solve it. The speed and accuracy in selecting and sorting relevant knowledge is crucial in problem-solving. As Effendi's statement (2012) that through problem-solving ability, students can solve their various problems, both in the mathematical problems as well as problems in daily life.

The mathematical problem-solving ability is not only important for students but also for prospective mathematics teachers. According to Widjajanti (2010), a prospective mathematics teacher must know, understand, and can apply the process of mathematical problem-solving. Because in the future they should guide the students to have ability of mathematical problemsolving.

But the facts, the learning process in college is too much emphasis on the doing aspect but less on the thinking aspect (Fahinu, 2007). What is taught in the classroom more concerned to manipulative skilled. Several results of research in Indonesia that showed the low ability of mathematical problem-solving at the level of prospective teachers' of mathematics as proposed by Widjajanti (2010), Karlimah (2010), and Prabawanto (2012)..

Therefore, as an effort to achieve the goal of learning mathematics, especially on improving mathematical problem-solving ability of students, researchers applied a reflective learning. According to Insuasty and Castillo (2010), the reflection should be a fundamental part for the development of teachers. It caused, teachers have an obligation to be able to evaluate and restructure capability of teaching in order to optimize the teaching-learning process. A reflective teacher too, must be able to be critical of his own teaching abilities so that students could get a dynamic learning experience, valuable and meaningful to their lives.

Furthermore Zeichner and Liston in Radulescu (2013) stated that the concept of reflective learning as a means to develop the professional capabilities of teachers. It is caused by the concept of reflective learning consists of several processes, which generally aims to foster an attitude of exploration and investigation so as to raise the awareness of prospective teachers as well as being factors that affect the learning process of students. The application of this 
learning model can improve the ability of students' mathematical thinking (Lasmawati 2011; Nainggolan, 2011; Rohana, 2015).

In the world of education, reflective learning has been developed by many education experts. So a lot of variety of reflective learning comes to us. One of reflective learning model is formulated by The International Center for Jesuit Education (ICAJE) is Ignatian Pedagogical Paradigm (Sirajuddin, 2009). Reflective learning that is based on the Ignatian Pedagogical Paradigm has been applied to the Jesuit schools worldwide (ICAJE, 1993). According Drost (Sirajuddin, 2009) concept of reflective thinking through reflective learning is the core of reflective learning. There are three major elements, namely experience, reflection (reflection), and action.

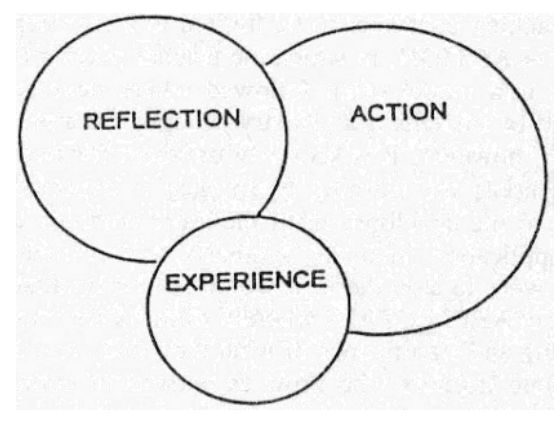

Figure 1. Ignatian Paradigm

(ICAJE, 1993)

To carry out these three elements, the supporting elements are required, pre-learning element (context) and post-learning element (evaluation). Thus, the reflective learning includes five steps such as: 1) context; 2) experience; 3) (reflection); 4) action; and 5) evaluation.

Based on the explanation above, the purposes of this study is determine the mathematical problem-solving ability of prospective teacher through the reflective learning. The indicator of the students' mathematical problem-solving abilitiy that were examined in this study include: (1) identify the adequacy of the data to solve the problem, (2) create a mathematical model and how to solve it, (3) select and implement strategies to solve mathematical problems and or outside mathematics, (4) explain and check the correctness of the answer.

\section{METHOD}

The subjects of this study were students of Mathematics Education Program of private universities in Palembang, consisting of 34 students. This study was conducted in $4^{\text {th }}$ semester academic year of 2015/2016. The instruments in this study were mathematical problemsolving ability test, observation sheet, and interviewing guide. The test consisted of six questions the description has been prepared based on indicators of mathematical problemsolving ability and has been declared valid and reliable. The data of students' mathematical problem-solving ability after their participation in reflective learning was collected. The data were analyzed descriptively.

The students' mathematical problem-solving ability is obtained by examining the test answer sheets according to the scoring rubric. Then the data were analyzed descriptively to see the achievement of mathematical problem-solving ability of students in the lecture. On average the final value obtained is used to view the categories of mathematical problem-solving ability 
of students. Interviews were conducted orally to students with different levels of mathematical skills. Interview data were analyzed descriptively and used as supporting data test mathematical problem-solving ability of students.

\section{RESULTS AND DISCUSSION}

\section{Results}

The learning activities are carried out in class 4A by the number of students as many as 34 people, divided into 7 groups with heterogeneous mathematical skills. The research was conducted as many as five sessions, with one test at the last meeting. Mathematical Statistics 1 material studied in this research is limited on Combinatorial Analysis, Probability and Conditional Probability. Researchers applied reflective learning at every meeting. The reflective learning includes five steps are as follows:

(1) Context.

Lecturers presented the topic of learning as new knowledge that will be discussed, and then do the debriefing to check the prerequisite knowledge and skills possessed by students. Lecturers are also directs students through the questions that triggered the students to relate their prior knowledge of the topic to be discussed.

(2) Experience.

Lecturer raises new issues related to the topic will be discussed and presented in the Student Worksheet (MFI). It is intended to stimulate the students understand their own thinking process. In this step, students examine the problems that arised, seeks to sharpen the problem and identify strategies for problem-solving, using these strategies to solve problems, and to determine the factors that allegedly led to the emergence of problems.

(3) Reflection.

Lecturer direct students to find a variety of information (collect data to support), formulated the layout and boundary issues, as well as the settlement of possible problems. Lecturers take a part as the facilitator and mediator to provide scaffolding for groups in need through reflection questions.

(4) Action.

Lecturers provide opportunities for students to present their answers and sharing in class discussions. Answers submitted student is not the result of an agreement because a student group may disagree with the group. Furthermore, lecturers steer students to be able to implement the settlement proceeds obtained (newly acquired knowledge of students) in other situations. In this case, the lecturer can give new problems as the continued problems related to issues that have been resolved by the students, that students should always modify the understanding that has been incorporated (prior knowledge) in order to solve new problems.

(5) Evaluation.

To determine individual student achievement to the topic that has been studied, lecturer evaluate by asking students to answer some questions. In addition, the lecturers also ask students to write a reflective journal as a training tool for students to be able to assess and monitor the success of the learning process. 
To obtain a picture of the quality of mathematical problem-solving ability of students, test data were analyzed descriptively. Summary of test results of mathematical problem-solving ability of students is presented in Table 1 .

Table 1. The Students' Mathematical Problem-solving Ability Test Result

\begin{tabular}{cll}
\hline Postest Score & Frequency & Category \\
\hline $81-100$ & 7 & Excellent \\
$61-80$ & 20 & Good \\
$41-60$ & 7 & Fairly \\
\hline
\end{tabular}

From Table 1, the result of mathematical problem-solving ability test students show the excellent categories equal to $20.59 \%$ ( 7 people), good categories equal to $50.82 \%$ (20 people), and fairly categories equal to $20.59 \%$ ( 7 people). While the test average score is 69.5 in good categories. The test results for each indicator mathematical problem-solving ability of students can be seen in Table 2 .

Table 2. The Score of Mathematical Problem-solving Ability for Each Indicator

\begin{tabular}{|c|c|c|c|}
\hline No. & $\begin{array}{l}\text { The indicator of students' } \\
\text { mathematical problem-solving ability }\end{array}$ & Average Score & Category \\
\hline 1. & $\begin{array}{l}\text { Identify the adequacy of the data to } \\
\text { solve the problem }\end{array}$ & 74,26 & Good \\
\hline 2. & $\begin{array}{l}\text { Create a mathematical model and } \\
\text { how to solve it. }\end{array}$ & 66,91 & Good \\
\hline 3. & $\begin{array}{l}\text { Select and implement strategies to } \\
\text { solve mathematical problems and or } \\
\text { outside mathematics }\end{array}$ & 60,29 & Fairly \\
\hline 4. & $\begin{array}{l}\text { Explain and check the correctness of } \\
\text { the answer }\end{array}$ & 70,59 & Good \\
\hline & Average & 69,49 & Good \\
\hline
\end{tabular}

\section{Discussion}

Results of this study have shown that the average mathematical problem-solving ability of students through the application of reflective learning falls into good categories. These findings reinforce and complement the results of previous research on reflective learning, among other research conducted by Nainggolan (2011), Lasmanawati (2011), and Rohana (2015) found that learning can improve the mathematical thinking ability.

In each steps of reflective learning, students are given the opportunity to play an active role in the learning process and are involved in considering the success of their learning. For example, in step experience, students are faced with a problem based questions that they are working in groups. Students are trained and familiarized reflective thinking mathematically through questions based on those problems. Social interaction through group discussions such as asking each other, respond or criticize answers friend, giving students the opportunity to have a very big role in the effort to understand the concepts, develop procedures, found the principles and apply the concepts, procedures, and principles in solving a given problem , 
In addition, according Hmelo \& Ferrari (Song, Koszalka, and Grabowski, 2005) lecturer's role as a facilitator in the reflective learning by giving instructions or scaffolding through questions reflections give to students to practice solving mathematical problems. The same thing also expressed Wahyudin (2008) that teachers have an important role in helping to empower the development of habits of reflective thinking by asking questions like: "Before we go, whether we believe already understand this?", "Why we think this is true ? ". These questions make students tend to learn responsibility to reflect on their own work and make the adjustments necessary when solving problems.

Based on the test results of mathematical problem-solving ability, it is known that the lowest average scores of students with enough catagory located on the third indicator, the ability to select and implement strategies to solve mathematical problems and or outside mathematics. This is the example of questions and answers of students to measure theirs ability in third indicators.

Dina is enjoying the original food in Palembang city. The menus which are available in 'Wak Aba' store are pempek, model, kemplang, and many kind of drinking. Pempek is including pempek telur, pempek kulit, pempek adaan, and pempek krupuk. Model is including model ikan and model gandum. Kemplang is consisting of fried kempang and baked kemplang. The drinking is consisting of peanut's ice and cincau ice. Determine in two different ways the illustration of Dina's choices to get

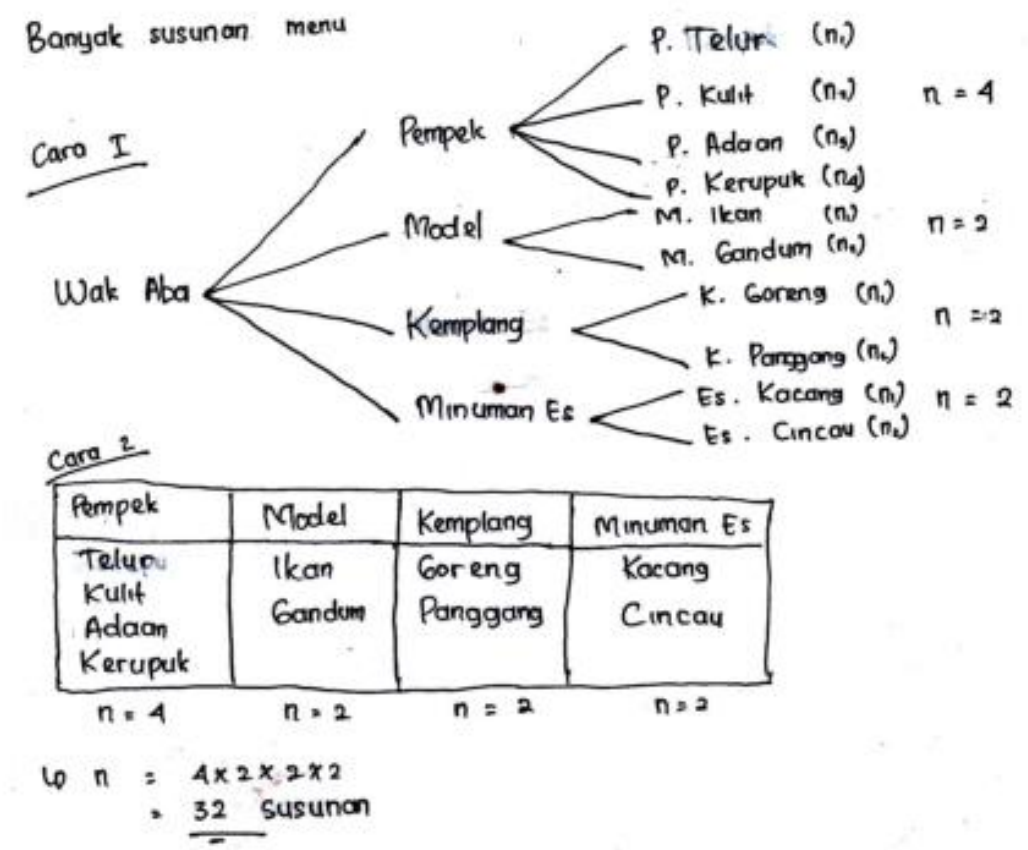

Figure 2. The result anwers for the third indicator

To solve the problem on this indicator, the student should be able to determine the number of ways or the structure menu that can be eaten by Dina. Students can use some solving 
strategies such as: a tree diagram, sequential pair, placement rules or the rules of multiplication. Figure 2 shows that the students used a tree diagram and placement rules to address these problems. Based on these answers, the third indicator has been reached.

Based on analysis of student work on this indicator, six students answered correctly and completely. Students who answered correctly but incomplete on this indicator only write one problem-solving strategies. This mistakes made by students when answering after further explored through an oral interview is a student did not interpret the question correctly. In addition, students who incorrectly answered caused due to poor understanding of the concept of algebra, so the problem of combinatorial analysis could not be solved correctly.

\section{CONCLUSION}

Based on the results of this study, concluded that the average score of students' mathematical problem-solving ability of students is fall into good category. From the analysis of problemsolving abilities per indicator, known to students classified as either on (1), (2) and (4), while quite indicator (3). Thus a good problem solvers, students are able to identify the adequacy of the data to solve the problem, is able to create a mathematical model of a problem and explain or check the correctness of the answer, but students are not quite capable of selecting and implementing a strategy to resolve the problem.

\section{REFERENCES}

Arthur, L. B. (2008). Problem-solving. U.S.: Wikimedia Foundation, Inc. [Online]. Available: http://en.wikipedia.org/wiki/ProblemSolving. [7 $7^{\text {th }}$ April 2008].

Effendi, L. A. (2012). Pembelajaran Matematika dengan Penemuan Terbimbing untuk Meningkatkan Kemampuan Representasi dan Pemecahan Masalah Matematis Siswa SMP. Jurnal Penelitian Pendidikan, 13(2), 1 - 10.

Fahinu. (2007). Meningkatkan Kemampuan Berpikir Kritis dan Kemandirian Belajar Matematika pada Mahasiswa melalui pembelajaran generatif. Bandung: Dissertasion in Mathematics Education, School of Post Graduate Studies, UPI.

ICAJE, The International Centre for Jesuit Education in Rome. (1993). Ignatian Pedagogy: A Practical Approach. [Online]. Available: http://www.rockhurst. edu/media/filer_private/ uploads/ignatian_pedagogy_apractical_approach.pdf. [2 $7^{\text {th }}$ Desember 2013].

Insuasty, E.A. dan Castillo, L.C.Z. (2010). Exploring Reflective Teaching through Informed Journal Keeping and Blog Group Discussion in the Teaching Practicum. PROFILE: Issues in Teachers' Professional Development Vol.12 No.2, October 2010. ISSN 1657-0790. Bogotá, Columbia. Pages 87-105.

Karlimah. (2010). Pengembangan Kemampuan Komunikasi dan Pemecahan Masalah serta Disposisi Matematis Mahasiswa PGSD melalui PBM. Bandung: Dissertasion in Mathematics Education, School of Post Graduate Studies, UPI.

Lasmanawati, A. (2011). Pengaruh Pembelajaran Menggunakan Pendekatan Proses Berpikir Reflektif terhadap Peningkatan Kemampuan Koneksi dan Berpikir Kritis Matematis Siswa. Bandung: Thesis in Mathematics Education, School of Post Graduate Studies, UPI. 
Nainggolan, L. (2011). Model Pembelajaran Reflektif untuk Meningkatkan Pemahaman Konsep dan Kemampuan Komunikasi Matematis. Bandung: Thesis in Mathematics Education, School of Post Graduate Studies, UPI.

Prabawanto, S. (2012). Peningkatan Kemampuan Pemecahan Masalah, Komunikasi, dan Self-Efficacy Matematis Mahasiswa melalui Pembelajaran dengan Pendekatan Metacognitive Scaffolding. Bandung: Disertation in Mathematics Education, School of Post Graduate Studies, UPI.

Radulescu, C. (2013). Reinventing Reflective Learning Methods in Teacher Education. Procedia - Social and Behavioral Sciences, 78, 11 - 15.

Rohana. (2015). Peningkatan Kemampuan Penalaran Matematis Mahasiswa Calon Guru Melalui Pembelajaran Reflektif. Infinity, 4(1), 105 - 119.

Sirajuddin. (2009). Model Pembelajaran Reflektif: Suatu Model Belajar Berbasis Pengalaman. In Didaktika Jurnal Kependidikan, 4(2), 189-200.

Song, H.D., Koszalka, T. A., dan Grabowski, B. (2005). Exploring Instructional Design Factors Prompting Reflective Thinking in Young Adolescents. In Canadian Journal of Learning and Technology, 31(2), 49-68.

Wahyudin (2003). Peranan problem-solving. Makalah Seminar Technical Cooperation Project for Development of Mathematics and Science for Primary and Secondary Education in Indonesi $a, 25^{\text {th }}$ Agustus 2003.

Widjajanti, D., B. (2010). Analisis Implementasi Strategi Perkuliahan Kolaboratif Berbasis Masalah dalam Mengembangkan Kemampuan Pemecahan Masalah, Kemampuan Komunikasi Matematis, dan Keyakinan terhadap Pembelajaran Matematika. Bandung: Disertation in Mathematics Education, School of Post Graduate Studies, UPI. 